\title{
Skills and training needs for use of electronic information resources (EIRs) among students in four Tanzanian Universities
}

\author{
Mugyabuso J. F. Lwehabura ${ }^{1}$ \\ Sokoine University of Agriculture, P. O. Box 3036 Morogoro, Tanzania \\ julwe@yahoo.com
}

\begin{abstract}
This article is based on a broader study that investigated the status and practice of Information Literacy (IL) for teaching and learning in four Tanzanian universities; namely Sokoine University of Agriculture (SUA), University of Dar-Es-Salaam (UDSM), Iringa University College (IUCO) and Saint Augustine University of Tanzania (SAUT). The primary intention of the study was to establish the best ways of introducing and improving IL programmes in these institutions. The article reports on the findings regarding students' knowledge, skill and training needs in using Electronic Information Resources (EIRs). Data was collected using a questionnaire-based survey administered to 1123 undergraduate students. Probability sampling was used to sample students across the four universities, faculties and years of study. The response rate was 59.1\%. The study findings revealed that although students in Tanzanian universities have access to and use various EIRs both for academic and non-academic work they still lack adequate knowledge and skills in some aspects, including searching and evaluation. The article therefore recommends the development of ICT infrastructures, that librarians and teaching staff become role models and mentors to students in using EIRs, and that teaching staff adopt an active learning and student-centred approach in their teaching as well as strengthening IL programmes as intervention measures for improving students' skills in using EIRs.
\end{abstract}

\section{Introduction}

In the current state-of-the-art of information technology, in parallel with print resources, many libraries and information centres have embraced the use of Electronic Information Resources (EIRs) including CD-ROM, the Internet, the world wide web (www) for provision of their information services, thus creating an opportunity for changes in education provision because of the advantages they have in simplifying the whole process of teaching, learning and research.

A number of reasons have led to the preference for EIRs by libraries and information centres, which include the ability to provide faster and easier access to current information by users in various places such as homes, offices and other workplaces,

\footnotetext{
${ }^{1}$ Mugyabuso J. F. lwehabura is a Senior Librarian at Sokoine University of Agriculture
} 
hostels and dormitories, easy storage and the possibility of sharing the same information resource among many users at a time, saving space, with relatively easy maintenance and easy linkage to indexing and abstracting databases.

The Internet for example, provides the opportunity to access a wide range of topics and media that enhance a variety of learning styles and the acquisition of knowledge and new ideas (Healey, 2003). When used effectively and skilfully the Internet also allows students and staff to search for and retrieve information from various sources including databases, electronic journals and books, newspapers and other publications for academic needs, research as well as for leisure purposes. This allows students to discover new things instead of looking at and memorising them thereby getting an opportunity to control their learning (Healey, 2003). The Internet also allows access to library resources for academic needs, and various official announcements posted by the authorities and so on. For most students the Internet is a functional tool that has changed their way of interacting with others and with information pertaining to their studies (Jones et. al., 2002). It is from this perspective that Anasi (2006) observes that the Internet is a vibrant tool that has created extraordinary chances for research, teaching, learning and publishing activities.

This article reports on the knowledge and skills relating to student's use of EIRs in four Tanzanian universities. It further highlights training needs regarding EIR use by Tanzanian university students. The article finally recommends some measures that can help to improve and create effective EIR use by students.

\section{Literature review}

A review of the literature in academic institutions reveals that because of the advantages offered by EIRs students, academic staff and researchers use a variety of electronic resources that include Online Public Access catalogues (OPACs), Compact Discs (CDROMs) and other resources offered through the Internet such as electronic journals, online databases, e-mail as well as e-print servers (Tenopir and King; Cochnour and 
Moothart, 2003). Because of their advantages these resources have become important tools for both students and staff in their academic and research activities.

Several studies focusing on people's behaviour, use, preference and problems relating to EIRs have been undertaken and their findings indicate that the intensity and pattern of use of EIRs differ from one user group to another. Differences in the use of EIRs have been identified among various information user groups in terms of age, gender, study programme or academic discipline, study or academic levels as well as motivation and task of an individual information seeker. For example, in terms of discipline some authors have established that experts in science, maths and medicine are more extensive users of EIRs than social scientists (Dillon and Hann, 2002; Hiller, 2002; Rowley, 2001). Differences in EIR use have also been reported within information users from related fields such as chemistry and physics, earth science and maths, business; finance and economics (Palmer and Sandler, 2003; Davis, 2002).

Tasks and motivation also create differences in terms of information seeking and use patterns. According to Nelson (2001) engagement in research creates more use of EIRs, specifically electronic journals, by researchers, academic staff and doctoral students (Palmer and Sandler, 2003; Monopoli et al., 2002; Sathe, Grandy and Giuse, 2002; Enochsson, A., 2005; Steinerová, J. and Šušol, J., 2007). Others have found that age and gender are among factors that lead to differences in EIR use.

Differences in EIR use can also be observed among graduate and undergraduate students. According to Rudner, Miller-Whitehead and Gellman, (2002), King and Montgomery, (2002), due to the nature of their studies that are based on research, graduate students use more EIRs than undergraduates, although within undergraduate students there are some differences according to disciplines (Whitmire, 2002).

Urquhart and Rowley (2007) have identified two types of factors that influence student's information behaviour, namely, micro and macro factors. Micro factors are those that impact directly specific student information behaviour while macro factors are those that 
define the context in which information behaviour occurs and may have an impact on micro factors. Urquhart and Rowley (2007) have further identified specific factors that impact on students' information behaviour.

Despite the importance and advantages offered by EIR, studies have identified a number of problems associated with their use by students. These problems range from lack or inadequate resources, mainly computers, and poor Internet connectivity, inappropriate usage and lack of appropriate skills among students. For example, studies by Malekani (2006) at Sokoine University of Agriculture; Luambano and Nawe (2004) at the University of Dar-Es-Salaam; Jagboro (2003) at the University- Obafemi Awolowo in Nigeria and Ojedokun (2001) at the University of Botswana showed that the use of the Internet and other EIRs by students was limited by an inadequate number of computers and access points.

Studies by Hung (2004); Luambano and Nawe (2004) and Ojedokun (2001) report lack of skills in searching the Internet as one of the limitations that affect its proper utilization. Ojedokun, (2001) contends that lack of effective searching skills has led most of the students to limit themselves to searching for and retrieving information on entertainment, sports and news from around the world instead of using the Internet for academic matters. In the same vein (Tadasad, Maheswarapa and Alur, 2003) observe that because of the lack of skills the use of the Internet by students is sometimes confined to general or recreational purposes.

\section{Methodology}

The study was conducted in four universities in Tanzania, namely Sokoine University of Agriculture (SUA), Saint Augustine University of Tanzania (SAUT), University of DarEs-Salaam (UDSM), Iringa University College (IUCO) ${ }^{2}$. The study employed the survey method, using self-administered questionnaires that were distributed to 1123 undergraduate students across faculties and years of study. The sample was obtained using probability sampling, whereby a list of all undergraduate students in each

\footnotetext{
${ }^{2}$ IUCO is a University College of Tumaini University
} 
university was created and the names were stratified according to students' faculties and year of study. In each stratified group a sample was picked systematically by making the selection at regular intervals from the sampling frame. Although there are no absolute criteria for sample selection and estimation, a formula and table devised and used by Krejcie and Morgan, (1970) to determine a sample size from a given population was applied. This table is widely accepted and used by researchers in the field of library and information science. Tables 1, 2, 3 and 4 give the details of the population and population sample for each university, while Table 5 shows the response rates.

Table $1 \quad$ Student sampling - SAUT

\begin{tabular}{|c|c|c|c|c|c|c|c|c|}
\hline \multirow[t]{2}{*}{ Faculty } & \multirow[t]{2}{*}{ Population } & \multicolumn{3}{|c|}{$\begin{array}{l}\text { Population per } \\
\text { year of study }\end{array}$} & \multirow{2}{*}{$\begin{array}{l}\text { Population } \\
\text { sample per } \\
\text { faculty }\end{array}$} & \multicolumn{3}{|c|}{$\begin{array}{l}\text { Population sample per } \\
\text { year of study }\end{array}$} \\
\hline & & $1 \mathrm{st}$ & 2nd & 3rd & & 1 st & 2nd & 3rd \\
\hline $\begin{array}{l}\text { Business } \\
\text { administration }\end{array}$ & $\begin{array}{r}187 \\
(53 \%)\end{array}$ & 123 & 40 & 24 & 99 & $\begin{array}{r}65 \\
(66 \%)\end{array}$ & $\begin{array}{r}21 \\
(21 \%)\end{array}$ & $\begin{array}{r}13 \\
(13 \%)\end{array}$ \\
\hline $\begin{array}{l}\text { Humanities and } \\
\text { Communication }\end{array}$ & $\begin{array}{r}168 \\
(47 \%)\end{array}$ & 86 & 46 & 36 & 87 & $\begin{array}{r}44 \\
(51 \%)\end{array}$ & $\begin{array}{r}24 \\
(27 \%)\end{array}$ & $\begin{array}{r}19 \\
(22 \%)\end{array}$ \\
\hline Total Population & 355 & & & & & & & \\
\hline University Sample & 186 & & & & & & & \\
\hline
\end{tabular}

Table 2 Students sampling- Iringa University College

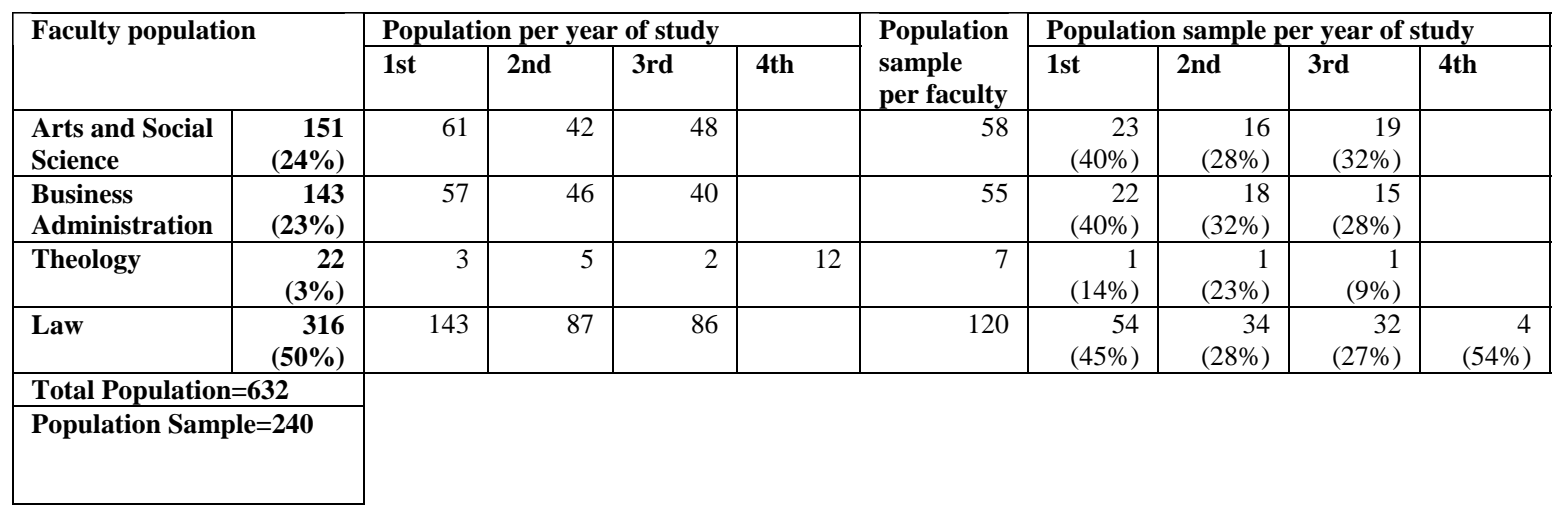


Table 3 Student sampling - SUA

\begin{tabular}{|c|c|c|c|c|c|c|c|c|c|c|c|c|}
\hline \multirow[t]{2}{*}{ Faculty } & \multirow{2}{*}{$\begin{array}{l}\text { Populatio } \\
\text { n }\end{array}$} & \multicolumn{5}{|c|}{ Population per year of study } & \multirow{2}{*}{$\begin{array}{l}\text { Populatio } \\
\text { n } \\
\text { sample } \\
\text { per } \\
\text { faculty }\end{array}$} & \multicolumn{5}{|c|}{ Population sample per years of study } \\
\hline & & 1st & 2nd & 3rd & 4th & 5th & & 1st & 2nd & 3rd & 4th & 5 th \\
\hline Agriculture & $\begin{array}{r}1533 \\
(69 \%)\end{array}$ & 518 & 521 & 470 & 24 & & 225 & $\begin{array}{r}74 \\
(33 \%)\end{array}$ & $\begin{array}{r}76 \\
(34 \%)\end{array}$ & $\begin{array}{r}70 \\
(31 \%)\end{array}$ & $\begin{array}{r}5 \\
(2 \%)\end{array}$ & \\
\hline $\begin{array}{l}\text { Forestry and } \\
\text { Nature } \\
\text { Conservation }\end{array}$ & $\begin{array}{r}313 \\
(14 \%)\end{array}$ & 102 & 102 & 109 & & & 46 & $\begin{array}{r}15 \\
(33 \%)\end{array}$ & $\begin{array}{r}15 \\
(33 \%)\end{array}$ & $\begin{array}{r}16 \\
(34 \%)\end{array}$ & & \\
\hline $\begin{array}{l}\text { Veterinary } \\
\text { Medicine }\end{array}$ & $\begin{array}{r}151 \\
(7 \%)\end{array}$ & 30 & 27 & 32 & 23 & 39 & 23 & $\begin{array}{r}5 \\
(20 \%)\end{array}$ & $\begin{array}{r}4 \\
(18 \%)\end{array}$ & $\begin{array}{r}5 \\
(21 \%)\end{array}$ & $\begin{array}{r}3 \\
(15 \%)\end{array}$ & $\begin{array}{r}6 \\
(26 \%)\end{array}$ \\
\hline Science & $\begin{array}{r}225 \\
(10 \%)\end{array}$ & 107 & 63 & 55 & & & 33 & $\begin{array}{r}16 \\
(48 \%)\end{array}$ & $\begin{array}{r}9 \\
(28 \%)\end{array}$ & $\begin{array}{r}8 \\
(24 \%)\end{array}$ & & \\
\hline Population & $\begin{array}{r}2222 \\
(100 \%) \\
\end{array}$ & 757 & 713 & 666 & 47 & 39 & & 112 & 105 & 97 & 8 & 6 \\
\hline $\begin{array}{l}\text { Population } \\
\text { sample }\end{array}$ & 327 & & & & & & & & & & & \\
\hline
\end{tabular}

\section{Table $4 \quad$ Students sampling - UDSM}

\begin{tabular}{|c|c|c|c|c|c|c|c|c|c|c|}
\hline \multirow[t]{2}{*}{ Faculty } & \multirow[t]{2}{*}{ Population } & \multicolumn{4}{|c|}{ Population per year of study } & \multirow{2}{*}{$\begin{array}{l}\text { Population } \\
\text { sample } \\
\text { per faculty }\end{array}$} & \multicolumn{4}{|c|}{ Population sample per year of study } \\
\hline & & 1st & 2nd & 3rd & 4th & & 1st & 2nd & 3rd & 4th \\
\hline Aquatic Science & $43(0.4 \%)$ & 31 & 12 & & & - & 0 & 0 & & \\
\hline Arts \& Social Science & $3481(36 \%)$ & 1260 & 1001 & 1045 & 175 & 133 & $\begin{array}{r}48 \\
(36 \%) \\
\end{array}$ & $\begin{array}{r}38 \\
(29 \%)\end{array}$ & $\begin{array}{r}40 \\
(30 \%) \\
\end{array}$ & $\begin{array}{r}7 \\
(5 \%)\end{array}$ \\
\hline Civil \& Built Materials & $403(4 \%)$ & 132 & 94 & 89 & 88 & 15 & $\begin{array}{r}5 \\
(33 \%) \\
\end{array}$ & $\begin{array}{r}4 \\
(23 \%) \\
\end{array}$ & $\begin{array}{r}3 \\
(22 \%) \\
\end{array}$ & $\begin{array}{r}3 \\
(22 \%) \\
\end{array}$ \\
\hline Commerce & $1386(14 \%)$ & 550 & 424 & 409 & 3 & 52 & $\begin{array}{r}21 \\
(40 \%) \\
\end{array}$ & $\begin{array}{r}16 \\
(31 \%) \\
\end{array}$ & $\begin{array}{r}15 \\
(29 \%) \\
\end{array}$ & \\
\hline $\begin{array}{l}\text { Chemical and chem. } \\
\text { Engineering }\end{array}$ & $504(5 \%)$ & 170 & 116 & 101 & 117 & 18 & $\begin{array}{r}6 \\
(34 \%) \\
\end{array}$ & $\begin{array}{r}5 \\
(23 \%) \\
\end{array}$ & $\begin{array}{r}4 \\
(20 \%) \\
\end{array}$ & $\begin{array}{r}4 \\
(20 \%) \\
\end{array}$ \\
\hline Education & $1253(13 \%)$ & 396 & 290 & 344 & 223 & 48 & $\begin{array}{r}15 \\
(31 \%) \\
\end{array}$ & $\begin{array}{r}11 \\
(23 \%) \\
\end{array}$ & $\begin{array}{r}13 \\
(27 \%) \\
\end{array}$ & $\begin{array}{r}9 \\
(18 \%) \\
\end{array}$ \\
\hline $\begin{array}{l}\text { Electrical \& Computer } \\
\text { Science }\end{array}$ & $373(4 \%)$ & 118 & 105 & 80 & 70 & 15 & $\begin{array}{r}5 \\
(32 \%) \\
\end{array}$ & $\begin{array}{r}4 \\
(28 \%) \\
\end{array}$ & $\begin{array}{r}3 \\
(21 \%) \\
\end{array}$ & $\begin{array}{r}3 \\
(19 \%)\end{array}$ \\
\hline IJMC & $96(1 \%)$ & 96 & & & & 4 & $\begin{array}{r}4 \\
(100 \%) \\
\end{array}$ & & & \\
\hline Law & $1028(11 \%)$ & 309 & 243 & 258 & 218 & 41 & $\begin{array}{r}12 \\
(30 \%) \\
\end{array}$ & $\begin{array}{r}10 \\
(24 \%) \\
\end{array}$ & $\begin{array}{r}10 \\
(25 \%) \\
\end{array}$ & $\begin{array}{r}9 \\
(21 \%) \\
\end{array}$ \\
\hline Science & 1119 (12\%) & 408 & 355 & 356 & & 44 & $\begin{array}{r}16 \\
(36 \%)\end{array}$ & $\begin{array}{r}14 \\
(32 \%)\end{array}$ & $\begin{array}{r}14 \\
(32 \%)\end{array}$ & \\
\hline Total Population & 9686 & & & & & & & & & \\
\hline $\begin{array}{l}\text { Population } \\
\text { Sample }\end{array}$ & 370 & & & & & & & & & \\
\hline
\end{tabular}


Table 5: Return rate of the questionnaires

\begin{tabular}{|l|r|r|r|}
\hline \multirow{2}{*}{ Institution } & \multicolumn{2}{|l|}{ Students } \\
\cline { 2 - 4 } & N & \multicolumn{1}{|l|}{ PS } & \multicolumn{2}{l|}{ RTN } \\
\hline SUA & 2222 & 327 & $\begin{array}{r}\mathbf{1 8 8} \\
(\mathbf{5 7 . 4 \% )}\end{array}$ \\
\hline UDSM & 9686 & 370 & $\begin{array}{r}\mathbf{2 1 1} \\
\mathbf{( 5 7 \% )}\end{array}$ \\
\hline IUCO & 632 & 240 & $\begin{array}{r}\mathbf{1 6 3} \\
\mathbf{( 6 7 . 9 \% )}\end{array}$ \\
\hline SAUT & 355 & 186 & $\begin{array}{r}\mathbf{1 0 2} \\
\mathbf{( 5 4 . 8 \% )}\end{array}$ \\
\hline Total & 12895 & 1123 & $\begin{array}{r}\mathbf{6 6 4} \\
\mathbf{( 5 9 . 1 \% )}\end{array}$ \\
\hline
\end{tabular}

Key:

(i) $\quad \mathrm{N}=$ Population in each University

(ii) PS = Sample size and number of distributed questionnaires

(iii) $\quad$ RTN $=$ Returned questionnaires

\section{Findings and discussion}

\section{Information search and use pattern}

In order to understand their information use pattern, students were provided with 19 information-seeking activities as indicated in Table 6 and were required to indicate how frequently they engaged in various activities for information seeking. Results in Table 6 show that students demonstrated a relatively even trend in their involvement in various activities for accessing and using information from various sources and by various means. However, there were four main activities in which students were actively involved, at frequencies that varied from every day to two to four times per week. These activities were using reference material in the library by $75.4 \%$ and searching the Internet for required academic information by 50.3\%. Other activities that had higher frequencies within a range of every day and two to four times per week are reading newspapers or magazines for local political, social and economic information by $72.8 \%$, while $60.6 \%$ read these sources for international political, social and economic information, and for local sports and leisure news. 
Table 6 Students' various information-seeking activities by frequency of occurrence

\begin{tabular}{|c|c|c|c|c|c|c|c|c|c|}
\hline \multicolumn{2}{|c|}{ Information seeking activities } & \multicolumn{8}{|c|}{ Frequency } \\
\hline & & $\begin{array}{l}\text { Every } \\
\text { day }\end{array}$ & $\begin{array}{l}\text { Two } \\
\text { to four } \\
\text { times } \\
\text { per } \\
\text { week }\end{array}$ & $\begin{array}{l}\text { Once } \\
\text { a week }\end{array}$ & $\begin{array}{l}\text { Once } \\
\text { every } \\
\text { two } \\
\text { weeks }\end{array}$ & $\begin{array}{l}\text { Once } \\
\text { a } \\
\text { month }\end{array}$ & $\begin{array}{l}\text { Less } \\
\text { than } \\
\text { once a } \\
\text { month }\end{array}$ & $\begin{array}{l}\text { Did } \\
\text { not } \\
\text { perfor } \\
\text { m any } \\
\text { for a } \\
\text { month }\end{array}$ & $\mathbf{N}$ \\
\hline 1 & Using reference material in the library & $\begin{array}{r}160 \\
(24.8 \% \\
\end{array}$ & $\begin{array}{r}326 \\
(50.6 \% \\
)\end{array}$ & $\begin{array}{r}80 \\
(12.4 \% \\
)\end{array}$ & $\begin{array}{r}26 \\
(4.0 \%)\end{array}$ & $\begin{array}{r}29 \\
(4.5 \%)\end{array}$ & $\begin{array}{r}13 \\
(2.0 \%)\end{array}$ & $\begin{array}{r}10 \\
(1.5 \%)\end{array}$ & $\mathrm{N}=644$ \\
\hline 2 & $\begin{array}{l}\text { Using the catalogue in the library to } \\
\text { locate relevant material identified }\end{array}$ & $\begin{array}{r}60 \\
(9.6 \%)\end{array}$ & $\begin{array}{r}161 \\
(25.7 \% \\
) \\
\end{array}$ & $\begin{array}{r}113 \\
(18.1 \% \\
)\end{array}$ & $\begin{array}{r}51 \\
(8.1 \%)\end{array}$ & $\begin{array}{r}56 \\
(8.9 \%)\end{array}$ & $\begin{array}{r}62 \\
(9.9 \%)\end{array}$ & $\begin{array}{r}123 \\
(19.6 \% \\
)\end{array}$ & $\mathrm{N}=626$ \\
\hline 3 & $\begin{array}{l}\text { Borrowing a book from the library's } \\
\text { general collection for personal academic } \\
\text { study }\end{array}$ & $\begin{array}{r}57 \\
(8.7 \%)\end{array}$ & $\begin{array}{r}159 \\
(24.9 \% \\
)\end{array}$ & $\begin{array}{r}135 \\
(21.2 \% \\
)\end{array}$ & $\begin{array}{r}94 \\
(14.7 \% \\
)\end{array}$ & $\begin{array}{r}76 \\
(11.9 \% \\
)\end{array}$ & $\begin{array}{r}45 \\
(7.1 \%)\end{array}$ & $\begin{array}{r}72 \\
(11.3 \% \\
)\end{array}$ & $\mathrm{N}=638$ \\
\hline 4 & $\begin{array}{l}\text { Using the short loan/special reserve/ East } \\
\text { Africana collection }\end{array}$ & $\begin{array}{r}49 \\
(7.9 \%)\end{array}$ & $\begin{array}{r}105 \\
16.8 \%)\end{array}$ & $\begin{array}{r}72 \\
(11.5 \% \\
) \\
\end{array}$ & $\begin{array}{r}34 \\
(5.4 \%)\end{array}$ & $\begin{array}{r}34 \\
(5.4 \%)\end{array}$ & $\begin{array}{r}51 \\
(8.2)\end{array}$ & $\begin{array}{r}279 \\
(44.7 \% \\
) \\
\end{array}$ & $\mathrm{N}=624$ \\
\hline 5 & $\begin{array}{l}\text { Borrowing a book from the library for } \\
\text { recreational reading }\end{array}$ & $\begin{array}{r}15 \\
(2.4 \%)\end{array}$ & $\begin{array}{r}72 \\
(11.3 \% \\
) \\
\end{array}$ & $\begin{array}{r}81 \\
(12.7 \% \\
) \\
\end{array}$ & $\begin{array}{r}46 \\
(7.2 \%)\end{array}$ & $\begin{array}{r}66 \\
(10.4 \% \\
) \\
\end{array}$ & $\begin{array}{r}89 \\
(14 \%)\end{array}$ & $\begin{array}{r}268 \\
(42.1 \%\end{array}$ & $\mathrm{N}=637$ \\
\hline 6 & Reserving a book that was out on loan & $\begin{array}{r}11 \\
(1.9 \%)\end{array}$ & $\begin{array}{r}36 \\
(6.1 \%)\end{array}$ & $\begin{array}{r}51 \\
(8.7 \%)\end{array}$ & $\begin{array}{r}29 \\
(4.9 \%)\end{array}$ & $\begin{array}{r}43 \\
(7.3 \%)\end{array}$ & $\begin{array}{r}45 \\
(7.6 \%)\end{array}$ & $\begin{array}{r}374 \\
(63.5 \% \\
\end{array}$ & $\mathrm{N}=589$ \\
\hline 7 & $\begin{array}{l}\text { Using a bibliography to find required } \\
\text { information }\end{array}$ & $\begin{array}{r}78 \\
(12.4 \% \\
) \\
\end{array}$ & $\begin{array}{r}133 \\
(21.2 \% \\
) \\
\end{array}$ & $\begin{array}{r}77 \\
(12.3 \% \\
) \\
\end{array}$ & $\begin{array}{r}48(7.6 \\
\%)\end{array}$ & $\begin{array}{r}63 \\
(10 \%)\end{array}$ & $\begin{array}{r}77 \\
(12.3 \% \\
) \\
\end{array}$ & $\begin{array}{r}152 \\
(24.2 \% \\
\end{array}$ & $\mathrm{N}=628$ \\
\hline 8 & $\begin{array}{l}\text { Using indexes or abstracts to find } \\
\text { required information }\end{array}$ & $\begin{array}{r}91 \\
(14.6 \% \\
) \\
\end{array}$ & $\begin{array}{r}136 \\
(21.9 \% \\
)\end{array}$ & $\begin{array}{r}73 \\
(1.7 \%)\end{array}$ & $\begin{array}{r}58 \\
(9.3)\end{array}$ & $\begin{array}{r}48 \\
(7.7 \%)\end{array}$ & $\begin{array}{r}59 \\
(9.5 \%)\end{array}$ & $\begin{array}{r}157 \\
(25.2 \% \\
)\end{array}$ & $\mathrm{N}=622$ \\
\hline 9 & $\begin{array}{l}\begin{array}{l}\text { Searching the Internet for required } \\
\text { academic information }\end{array} \\
\end{array}$ & $\begin{array}{r}109 \\
(17.2 \% \\
)\end{array}$ & $\begin{array}{r}209 \\
(33.1 \% \\
) \\
\end{array}$ & $\begin{array}{r}118 \\
(18.7 \% \\
) \\
\end{array}$ & $\begin{array}{r}51 \\
(8.1 \%)\end{array}$ & $\begin{array}{r}55 \\
(8.7 \%)\end{array}$ & $\begin{array}{r}34 \\
(5.4 \%)\end{array}$ & $\begin{array}{r}56 \\
(8.9 \%)\end{array}$ & $\mathrm{N}=632$ \\
\hline 10 & $\begin{array}{l}\text { Downloading or reading a journal article } \\
\text { from online journals }\end{array}$ & $\begin{array}{r}28 \\
(4.55 \% \\
)\end{array}$ & $\begin{array}{r}95 \\
(15.1 \% \\
) \\
\end{array}$ & $\begin{array}{r}85 \\
(13.5 \% \\
) \\
\end{array}$ & $\begin{array}{r}54 \\
(8.6 \%)\end{array}$ & $\begin{array}{r}70 \\
(11.1 \% \\
) \\
\end{array}$ & $\begin{array}{r}86 \\
(13.7 \% \\
) \\
\end{array}$ & $\begin{array}{r}210 \\
(33.4 \% \\
) \\
\end{array}$ & $\mathrm{N}=628$ \\
\hline 11 & $\begin{array}{l}\text { Using CD-ROM in the library to locate } \\
\text { required information }\end{array}$ & $\begin{array}{r}15 \\
(2.4 \%)\end{array}$ & $\begin{array}{r}51 \\
(8.1 \%)\end{array}$ & $\begin{array}{r}43 \\
(6.8 \%)\end{array}$ & $\begin{array}{r}40 \\
(6.3 \%)\end{array}$ & $\begin{array}{r}51 \\
(8.1 \%)\end{array}$ & $\begin{array}{r}89 \\
(14.1 \% \\
)\end{array}$ & $\begin{array}{r}344 \\
(54.3)\end{array}$ & $\mathrm{N}=633$ \\
\hline 12 & $\begin{array}{l}\text { Searching the Internet for recreational } \\
\text { purposes e.g. Music, sports, fashion and } \\
\text { design, celebrities etc. }\end{array}$ & $\begin{array}{r}62 \\
(9.6 \%)\end{array}$ & $\begin{array}{r}115 \\
(17.7 \%\end{array}$ & $\begin{array}{r}116 \\
(17.9 \% \\
)\end{array}$ & $\begin{array}{r}52 \\
(8 \%)\end{array}$ & $\begin{array}{r}50 \\
(7.7 \%)\end{array}$ & $\begin{array}{r}71 \\
(11 \%)\end{array}$ & $\begin{array}{r}182 \\
(28.1 \% \\
)\end{array}$ & $\mathrm{N}=648$ \\
\hline 13 & $\begin{array}{l}\text { Reading newspapers or magazines for } \\
\text { local political, social, and economic } \\
\text { information }\end{array}$ & $\begin{array}{r}308 \\
(47.3 \% \\
)\end{array}$ & $\begin{array}{r}166 \\
(25.5 \% \\
)\end{array}$ & $\begin{array}{r}89 \\
(13.7 \% \\
)\end{array}$ & $\begin{array}{r}25 \\
(3.8 \%)\end{array}$ & $\begin{array}{r}22 \\
(3.4 \% 0\end{array}$ & $\begin{array}{r}18 \\
(2.8 \%)\end{array}$ & $\begin{array}{r}23 \\
(3.5 \%)\end{array}$ & $\mathrm{N}=651$ \\
\hline 14 & $\begin{array}{l}\text { Reading newspapers or magazines for } \\
\text { international political, social and } \\
\text { economic information }\end{array}$ & $\begin{array}{r}256 \\
(40.6 \% \\
)\end{array}$ & $\begin{array}{r}174 \\
(26.7 \% \\
)\end{array}$ & $\begin{array}{r}101 \\
(15.5)\end{array}$ & $\begin{array}{r}24 \\
(3.7 \%)\end{array}$ & $\begin{array}{r}40 \\
(6.1 \%)\end{array}$ & $\begin{array}{r}28 \\
(4.3 \%)\end{array}$ & $\begin{array}{r}20 \\
(3.1 \%)\end{array}$ & $\mathrm{N}=652$ \\
\hline 15 & $\begin{array}{l}\text { Reading newspapers or magazines for } \\
\text { local sports and leisure news }\end{array}$ & $\begin{array}{r}257 \\
(39.9 \% \\
)\end{array}$ & $\begin{array}{r}133 \\
(20.7 \% \\
)\end{array}$ & $\begin{array}{r}87 \\
(13.5 \% \\
)\end{array}$ & $\begin{array}{r}32 \\
(5 \%)\end{array}$ & $\begin{array}{r}26 \\
(4 \%)\end{array}$ & $\begin{array}{r}28 \\
(5.9 \%)\end{array}$ & $\begin{array}{r}71 \\
(11 \%)\end{array}$ & $\mathrm{N}=644$ \\
\hline 16 & $\begin{array}{l}\text { Reading newspapers or magazines for } \\
\text { international sports and leisure news }\end{array}$ & $\begin{array}{r}222 \\
(34.6 \% \\
) \\
\end{array}$ & $\begin{array}{r}145 \\
(22.6 \% \\
) \\
\end{array}$ & $\begin{array}{r}87 \\
(13.6 \% \\
) \\
\end{array}$ & $\begin{array}{r}34 \\
(5.3 \%)\end{array}$ & $\begin{array}{r}28 \\
(4.4 \%)\end{array}$ & $\begin{array}{r}49 \\
(7.6 \%)\end{array}$ & $\begin{array}{r}76 \\
(11.9)\end{array}$ & $\mathrm{N}=641$ \\
\hline 17 & $\begin{array}{l}\text { Using e-mail for sending or requesting } \\
\text { educational information }\end{array}$ & $\begin{array}{r}62 \\
(9.7 \%)\end{array}$ & $\begin{array}{r}155 \\
24.2 \%)\end{array}$ & $\begin{array}{r}103 \\
(16.1 \% \\
)\end{array}$ & $\begin{array}{r}45 \\
(7 \%)\end{array}$ & $\begin{array}{r}54 \\
(8.4 \%)\end{array}$ & $\begin{array}{r}65 \\
(10.8 \% \\
)\end{array}$ & $\begin{array}{r}153 \\
(23.9 \% \\
)\end{array}$ & $\mathrm{N}=641$ \\
\hline 18 & $\begin{array}{l}\text { Using e-mail to communicate with friend } \\
\text { or relative }\end{array}$ & $\begin{array}{r}80 \\
(12.4 \% \\
) \\
\end{array}$ & $\begin{array}{r}178 \\
(27.7 \% \\
)\end{array}$ & $\begin{array}{r}160 \\
(24.9 \% \\
)\end{array}$ & $\begin{array}{r}54 \\
(8.4 \%)\end{array}$ & $\begin{array}{r}56 \\
(8.7 \%)\end{array}$ & $\begin{array}{r}30 \\
(4.7 \%)\end{array}$ & $\begin{array}{r}85 \\
(13.3 \% \\
)\end{array}$ & $\mathrm{N}=643$ \\
\hline 19 & $\begin{array}{l}\text { Asking a librarian for help to find } \\
\text { information }\end{array}$ & $\begin{array}{r}70 \\
(10.0 \% \\
)\end{array}$ & $\begin{array}{r}130 \\
(20.2 \% \\
\end{array}$ & $\begin{array}{r}89 \\
(13.8 \% \\
)\end{array}$ & $\begin{array}{r}38 \\
(5.9 \%)\end{array}$ & $\begin{array}{r}84 \\
(13 \%)\end{array}$ & $\begin{array}{r}11 \\
(18.5 \% \\
)\end{array}$ & $\begin{array}{r}114 \\
(17.7 \% \\
)\end{array}$ & $\mathrm{N}=644$ \\
\hline
\end{tabular}


However, for the purpose of this article detailed discussion focuses on items that are directly related to the use of EIRs. From table 6 the following can be observed:

- $\quad$ Of 628 students 28 (4.5\%) and 95 (15.1\%) downloaded an online journal article every day and two to four times a week.

- $\quad$ Of 628 students 86(13.7\%) downloaded an online journal article only once a month while 210 (33.4\%) did not download any online journal article for the whole month

- $\quad$ Of 632 students 109 (17.2\%) and 209 (33.1\%) searched the Internet for required academic information every day and two to four times a week

- $\quad$ Of 648 students 62 (9.6\%) and 115 (17.7\%) students searched the Internet for recreational purposes e.g. Music, sports, fashion and design, celebrities, etc., every day and two to four times a week

- $\quad$ Of 641 students 62 (9.7\%) and 145 (22.6\%) used e-mail for sending or requesting educational information every day and two to four times a week

- $\quad$ Of 643 students 80 (12.4\%) and 155 (24.2\%) used e-mail to communicate with a friend or relative every day and two to four times a week

- $\quad$ Of 633 students 433 (68.4\%) did not use CD-ROM databases for the whole month.

\section{Confusion and difficulty in using electronic information sources}

Given the nature of information proliferation, information users are confronted with vast quantities of information that results in confusion on where and how to get the intended information. Students were asked to give their opinions on whether a wide range of sources created confusion or difficulty for them in terms of comprehending, selecting and using the information sources appropriately and effectively. The results indicted that 496 (74.7\%) respondents agreed that the availability of information from a wide range of sources created difficulty and confusion for them, while 168 (25.3\%) said they did not face difficulties. Of the 496 respondents 171 gave their reasons for confusion and difficulties as follows: 
(i) Lack of knowledge and skills on how to use some of those information resources was mentioned by 98 (57.3\%) respondents.

(ii) Insufficient information evaluation skills were mentioned by 73 (42.7\%) respondents.

With these responses it was clear that, although Tanzanian university students had access to a wide range of information resources, their usage was hampered by lack of skills that would allow them to exploit the resources more efficiently.

\section{Use of CD-ROM databases}

CD-ROM databases both in bibliographic and full-text format provide comprehensive and reliable academic information. CD-ROMs form part of the EIR collection provided by Tanzanian University libraries. However, the study findings indicated that the rate of CD-ROM use by students in the universities under study was very low. This was indicated by 433 (68.4\%) students out of 633 who did not use CD-ROM databases for the whole month compared with 62 (10.5\%) who used them within a range of every day to two to four times per week. Low level of CD-ROM use indicates students’ lack of skills.

\section{Use of the Internet}

In this study students were asked a number of questions relating to the use of the Internet. Firstly they were asked to rate the usefulness of the Internet by indicating "Very useful”, "Useful" and "Not useful" for in meeting their academic information needs. The results showed that 368 (55.4\%) rated the Internet as Very useful, 281 (42.3\%) as Useful and 15 $(2.3 \%)$ as Not useful. These statistics confirm that students valued Internet in meeting their information needs. In order to find out precisely how they used it, students were asked to identify the three search engines that they frequently used. Seventeen search engines were named. The three most used search engines were Google.com that was mentioned by 545 (82\%), Yahoo.com that was noted by 411 (61.8\%) and Msn.com that was given by 108 (16.2\%). From Table 6 it is shown that out of 632 students 318 (50.3\%) used the Internet to search for required academic information within a range of every day and two to four times a week while 207 (32.3\%) out of 641 students used e-mail for sending or requesting educational information every day and two to four times a week. 
177 (27.3\%) out of 648 students searched the Internet for recreational purposes such as music, sports, fashion and design, celebrities and so on within a range of every day and two to four times a week, while 235 (36.6\%) out of 643 used e-mail for communicating with their friends and relatives. From this study it is evident that students widely use the Internet for both academic and non-academic purposes, thus confirming other studies by (Buschman and Warner, 2005; Lombardo and Miree, 2003; Ojedokun, 2001 and McBridge and Dickstein, 1998).

However, it is the skills employed by students in their use of the Internet that is of more concern. The study revealed some obvious weaknesses in terms of students' knowledge and skills in using the Internet as 101 (16.2\%) and 242 (38.7\%) rated their skills for searching the Internet with various search engines as lower and lowest respectively. This confirmed that students' use of the internet is motivated by its convenience and not necessarily by their possession of the requisite skills for its effective use.

\section{Evaluating internet resources}

While any Internet user is able to browse it and find information using any search engine, the most important thing, especially for students, is the accuracy and reliability of the information found, which requires skills to enable an individual to judge the value of the Internet information. Students were therefore asked to state the criteria they used in order to determine the credibility of the information they get when searching the Internet. Three main criteria were mentioned, namely:

- $\quad$ Relevance of the information in relation to the subject of the search cited by 368 (55.5\%) respondents

- $\quad$ Source of information meaning the authority or author of the information cited by 233 (35.1\%) respondents

- $\quad$ Currency of the publication cited by 62 (9.4\%) respondents

Looking at the above responses it can be agreed that students were relatively aware of some of the criteria that can be applied to evaluate some Internet information. Relevance of the information in relation to the subject was the main criterion for Internet information credibility, followed by source (authority or author) and lastly the currency 
of the publication. There is a need therefore to ensure that through information literacy programmes students are equipped with the appropriate knowledge and skills for effective Internet resource use including evaluation. This is important especially taking into consideration that a large amount of information from the Internet does not go through rigorous editing and scrutiny in order to determine its authenticity and verification of its accuracy, as is the case for most journals and other traditional print resources.

\section{Use of online journals}

Journal articles are very important information sources because in most cases they provide recent information that has been researched by experts and scholars on specific fields. In addition, journal articles, unlike much of the information published in the Internet, undergo rigorous reviews before being published. Although most university libraries in developing countries, including countries in Sub-Saharan Africa, lack current academic information resources including books and journals due to budgetary constraints, in Tanzania all universities and other academic institutions have access to the full-text of online journals provided by International Network for Availability of Scientific Publications (INASP) through the Programme for the Enhancement of Research Information (PERI). This study found that only 123 (19.6\%) students read or downloaded journal articles every day or in a range of two to four times per week as compared with 296 (47.1\%) who did not download an article for the whole month. Even bearing in mind the nature of undergraduate students' studies, online journal use appears to be low in a situation of paucity of other up-to-date resources. Two factors can be considered in relation to this problem; lack of awareness of the availability of services and lack of resources. This problem can be attributed first, to the poor or lack of awareness of current services by students and to the staff that are supposed to be provided by libraries. Second, this may be a reflection of lectures teaching approaches in particular their emphasis on the use of various information resources, including online journals. This is to say that if lecturers do not instruct their students to use the available online journals, students are unlikely to use them. Poor use of other EIRs by students is a manifestation of their reliance on their lecturers' materials that again mirrors the teaching 
methods used by lecturers. Reliance on materials prescribed by lecturers is a reflection of teaching approaches applied by lecturers. It can be difficult for students to become effective users of certain EIRs if lecturers do not use them and do not encourage the students to use them. Methods of instruction in higher education in developing countries have often been criticized for being too traditional in the sense that they are "spoon feeding” students, who rely heavily on their lecturers' lectures and on prescribed textbooks. In this study there is a support for this criticism because 419 (66.6\%) students reported to prefer textbooks prescribed by their lecturers when working on their assignment, followed by 308 (51.1\%) who preferred handouts and other materials

provided by lecturers. The tendency of relying on the materials prescribed by lecturers is also observed among students at the University of Botswana (Ojedokun and Lumande, 2005).

\section{Students' training needs}

In an academic environment, information is a vital input for all learning, teaching and research activities. Information that is needed to fulfil those purposes is available in both electronic and non-electronic formats. However, most information required to support assembling academic and professional careers requires extensive literature searching and the garnering of ideas from different sources and in different formats. Thus, individuals who are able to use the right information from the right source at the right time stand a better chance of succeeding in their endeavours than those who cannot do so. In this regard, students' knowledge and skills for searching, locating, retrieving, evaluating, and analysing information from various sources is vital because collectively they enhance students' comprehension and handling of information and its effective use.

Students were asked to give their views as to whether there was a need for them to be given special training in the use of two EIRs, namely, online academic databases and using the Internet. For online databases 600 (90.4\%) students agreed that there was need for training, two (0.3\%) did not agree and 62 (9.3\%) were uncertain. Regarding the need for Internet training 606 (91.3\%) respondents were in favour of the training, four (0.6\%) were against training and 54 (8.1\%) were uncertain. 
In terms of specific training needs students were asked to rate their training priority in five aspects. Table 7 indicates students' training priority for each aspect. Very high score of 381 (63.8\%) and 360 (60.6\%) indicated that students needed training in searching for information from electronic sources and knowledge about using electronic sources respectively. Other scores for first priority for training were 254 (44.9\%) for topic analysis and 216 (38.6\%) for formulation of search strategy as the first priority.

\section{Table $7 \quad$ Students priority for training in IL aspects}

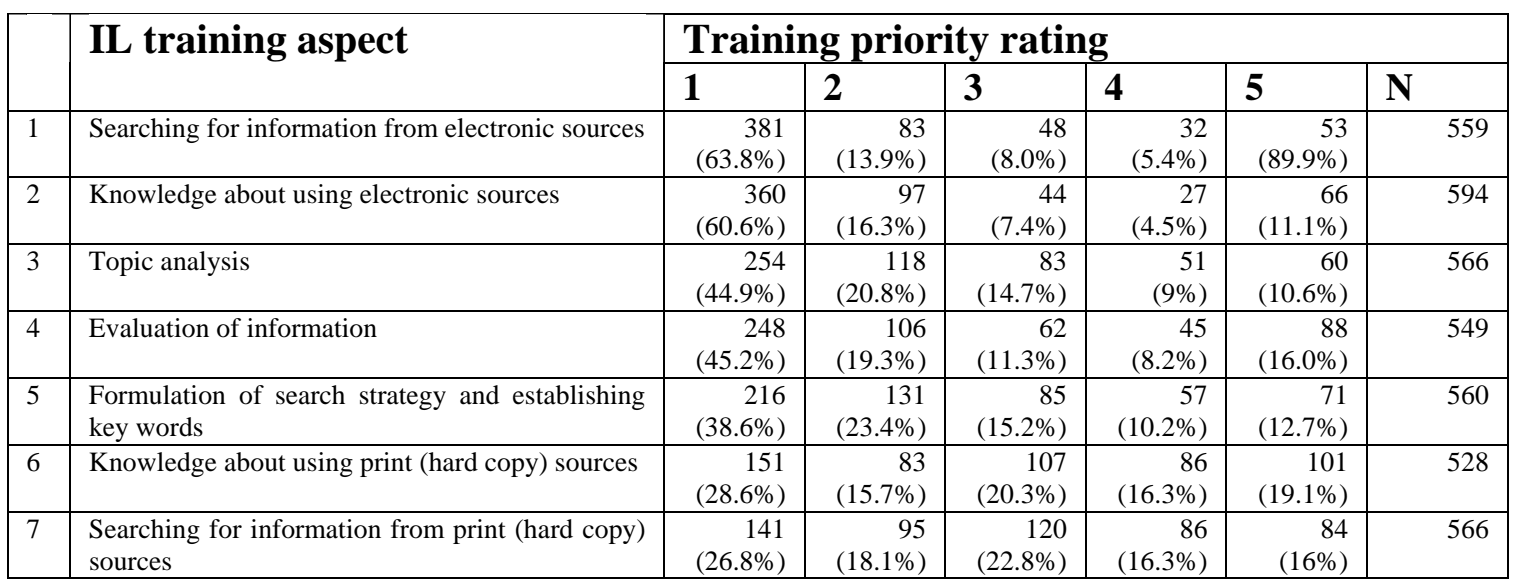

Only 151 (28.6\%) opted as a first priority for the use of print sources (hard copies), while 141 (26.8\%) opted for searching for information from print (hard copy) sources, as their first priority. Similar results were found from the study by (Malekani, 2006) that showed that 84 (86\%) out of 102 students preferred using the Internet compared with 14(14\%) who preferred using other information sources. This study revealed further that the reasons for Internet preference were the presence of current information by 42 (72\%), easy retrieval by 36 (62.1\%), speed by 33 (56.9\%), comprehensiveness of information by18 (31\%) and enjoyment found by 14 (24.1\%).

The point to emphasise here is that students should acquire all round skills and competencies in all types of information sources regardless of their formats. 


\section{Conclusions}

EIRs form basic information resources in Tanzanian university libraries. Universities have made considerable investment in ICT and EIRs in general (Kiondo, 2004). However the study findings demonstrate that students' levels of EIR use are not commensurate with the necessary skills. This was shown by a high percentage of students (74.7\%) who confirmed their difficulties and confusion in using EIRs, low frequency of use of online journals and by the high number of students with a desire and need for training in various aspects of EIR use. This deficiency among other reasons emanates from the lack of an IL programme necessary for imparting the requisite skills to students. It is important to equip students with the knowledge and skills in using EIRs in terms of searching, retrieving and evaluating in a more critical manner so that students can become effective and efficient information users.

\section{Recommendations}

Since EIR use by students is influenced by many factors, in order to maximise and achieve effective and efficient use of EIRs by students, universities should take the following into consideration:

- Ensure that their ICT infrastructure is good and stable to support teaching and learning using EIRs

- Librarians and teaching staff should make sure that they update their skills in the use of EIRs and be able to transfer the skills they have to their students.

- Teaching staff should adopt pedagogy that involves EIRs as their tool for teaching using active learning and student-centred approach.

- Tanzanian universities should introduce and adopt systematic and comprehensive information literacy programmes that would ensure that all students are exposed to constant and all-round training in various (IL) aspects.

\section{References}

Anasi, S. (2006). "Internet use pattern of undergraduate students at the University of Lagos, Nigeria.” University of Dar-Es-Salaam Library Journal, 8 (1/2), 1-14.

Andretta, S. (2006). "Information literacy: challenges of implementation". http://wwwics.heacademy.ac.uj/italics/vol5-/pdf/Saeditorial_final06Jan.pdf (Accessed 2006 June $\left.13^{\text {th }}\right)$. 
Ashcroft, L. and Watts, C. (2005). "ICT skills for information professionals in developing countries: perspectives from a study of the electronic environment in Nigeria.” IFLA Journal, 31 (1), 6-12.

Buschman, J. and Warner, D. A. (2005). "Researching and shaping information literacy initiatives in relation to the web: some framework problem and need." Journal of Academic Librarianship, 31 (1), 12-18. http://www.science direct.com/science (Accessed 2005 October $12^{\text {th }}$ ).

Cochenour, D. and Moothart, T. (2003). "E-journal acceptance at Colorado State University: a case study.” Serial Review, 29 (1), 16-25.

Davis, P. M. (2002]. "Patterns in electronic journal usage: challenging the composition of geographic consortia." College and Research Libraries, 63 (6), 484-497.

Dillon, I. and Hahn, K. (2002). "Are researchers ready for the Electronic-Only journal collection: results of a survey at the University of Maryland"? Portal-Libraries and the Academy. 2 (3), 375-390.

Enochsson, A. (2005). A gender perspective on Internet use: consequences for information seeking. Information Research, 10 (4), Paper 237.

http://informationr.net/ir/10-4/paper237.html. (Accessed 2007 April 10 ${ }^{\text {th }}$ )

Griffiths, J. and Brophy, P. (2005). "Students search behaviour and the Web; use of academic resources and Google.” Library trends, 53 (4), 539-554.

Healey, D. (2003). "Advantages and limitations of computers and the Internet for classroom teacher". http://www.oregonstate.edu/ haleyd/upc/advdisadv.html (Accessed 2005 January $\left.4^{\text {th }}\right)$.

Hiller, S. (2002). "How different are they? A comparison by academic area of library use, priorities and information needs at the University of Washington.” Issues in Science and Technology Librarianship. http://www.istl.org/istl/02-winter/article1.html. (Accessed 2004 May $3^{\text {rd }}$ )

Hong, K. S., Ridzuan, A. A. and Kuek, M. K. (2002). “Students' attitudes towards the use of the internet for learning: a study at the University of Malaysia." Educational Technology and Society, 6 (2), 45-49. http://ifets.ieee.org/periodical/6-2/5.html (Accessed 2004 June $1^{\text {st }}$ ).

Hung, T. (2004). "Undergraduate students' evaluation criteria when using Web resources for class paper." Journal of Educational Media and Library Science, 42 (1), 1-12. http://research.dils.tku.edu.tw/jouemis (Accessed). 
Idiodi, E. A. (2005). “Approaches to information literacy in Nigeria.” Library Review, 54 (4), 223-230.

Jagboro, K. (2003). “A study of Internet usage in Nigeria Universities: a case study of Obafemi Owolowo University, Ile Ife, Nigeria.” First Monday, 8 (2) http://www.firstmonday.org/issues8 2/jogboro/ (Accessed 2005 July $12^{\text {th }}$ ).

Jones, S. et. al (2002). "The Internet goes to college: how students are living in the future with today’s technology”. http://www.pewinternet.org/ (Accessed 2004 May $5^{\text {th }}$ ).

King, D. and Montgomery, C. (2002). "After migration to an electronic journal collection.” D-lib magazine 8 (12).

http://www.dlib.org/dlib/december02/king/12king.html (Accessed 2004 February 23 ${ }^{\text {rd }}$ )

Kiondo, E., (2004). An assessment of levels of IT investments, electronic information resource usage and information literacy skills of users at the University of Dar-EsSalaam. Sixth Standing Conference of African National and University Libraries in Eastern, Central and Southern Africa, Kampala, Uganda, 2nd-4th July 2004, Kampala: SCANUL-ECS. 37- 49.

Krejcie, R. V. and Morgan, D. W. (1970). "Determining sample size for research activities.” Educational and Psychological Measurements (Autumn), 607-610.

Lombardo, S. V. and Miree, C. E. (2003). "Caught in the web: the impact of library instruction on business students' perception and use of print and online resources." College and Research Libraries 64(January), 6-22.

Luambano, I. and Nawe, J. (2004). "Internet use by students at the University of Dar-EsSalaam.” Library High Tech News, 21 (10), 113-17.

Mcbridge, K. B. and Dickstein, R. (1998). "The Web demands critical reading by students." Chronicle of Higher Education 54:28.

McDowell, L (2002). "Electronic information resources in undergraduate education: an exploratory study of opportunities for student learning and independence.” British Journal of Educational Technology, 33 (3), 255-266.

Malekani, A.W. (2006). “A study of students Internet perceptions at Sokoine University of Agriculture, Republic of Tanzania”. Msc. Thesis. (Information Studies) University of Dar-Es-Salaam.

May, C. (2002). “The information society: a sceptical view.” Poly Press/Blackwell Publishing Ltd, Malden

Meola, M. (2004). "Chucking the checklist: a contextual approach to teaching undergraduates Web-site evaluation.” Portal: Libraries and the Academy, 4 (3), 331-344. 
http://jhu.edu/journal/portal_libraries_and the_academy/toc/pla4.3.html (Accessed 2006 May $16^{\text {th }}$ )

Monopoli, M. et al. (2002). "A user-oriented evaluation of digital libraries: a case study: The electronic journals' services of the library and information services of the University of Petras Greece.” Aslib Proceedings 54 (2), 103-117.

Montgomery, C. and King, D (2002). "Comparing library user related costs of print and electronic journal collections: a first step towards a comprehensive analysis”. D-lib magazine 8 (10). http://www.dlib.org/dlib/october02/montegomery/10 ontegomery.html (Accessed 2004 August 11 ${ }^{\text {th }}$ )

Nelson, D. (2001). "The uptake of electronic journals by academics in the UK, their attitudes towards them and their potential impact on scholarly communication." Information Services and Use, 21 (3-4), 205-214.

Ojedokun, A. (2001). "Internet access and use by students of the University of Botswana.” African Journal of Library, Archives and Information Science 11 (2), 97-107.

Ojedokun, A. A. and Lumande, E. (2005). "The integration of information literacy skills into a credit-earning programme at the University of Botswana." African Journal of Library, Archives and Information Science, 15(2), 117-124.

O’Sullivan, M. and Scott, T. J. (1999). "Information literacy and the World Wide Web.” Classroom Leadership, 3 (2). Available

http://www.ascd.org/publications/class_lead/199910/osullivan.html (Accessed 2004 April $5^{\text {th }}$ )

Palmer, J. and Sandler, M. (2003). “What do faculty want?” Netconnect (Winter) 26-28.

Ramsey, S. (2004), How to Find Information: A Guide for Researchers, Open University Press, Berkshire.

Rockman, I. F. (2002). "Strengthening connections between information literacy, general education and assessment efforts.” Library Trends, 51 (2), .185-198.

Rowley, J. (2001). "JISC user evaluation monitoring and evaluation framework" Ariaden, 30 http://www.ariadne.ac.uk/issue30/jisc/intro.html (Accessed 2005 October $2^{\text {nd }}$ )

Sathe, N., Grady, J. and Nunzia, G. (2002). "Print versus electronic journals: a preliminary investigation into the effect of journal format for research process." Journal of the Medical Library Association, 90 (2), 235-243.

Scott, T. and O’Sullivan, M. (2000). “The Internet and information literacy: taking the first step towards technology education in the social studies." Social Studies, 91 (3), 121126. 
Steinerová, J. and Šušol, J. (2007). "Users' information behaviour - a gender perspective." Information Research, 12(3) paper 320. http://InformationR.net/ir/123/paper320.html] (Accessed 2007 September 1st)

Tadasad, P. G., Maheswarappa, B. S. and Alur, S. A. (2003). "Use of Internet by undergraduate students of P.D.A. College of Engineering, Gulbarga." Annals of Library and Information Studies, 50 (1)0, 31-42.Available http://wotan.liu.edu.dois/data/articles/igiannlsv:50:y:2003:I:1:p:31-42.html (Accessed 2005 June $3^{\text {rd }}$ )

Tenopir, C. Pollard, R. and Wang, P. (2003). Increasing effective student use of the scientific journal literature. http://web.utk.edu/ tenopir/nsf/index.html (Accessed 2007 August $22^{\text {nd }}$ )

Urquhart, C. and Rowley, J. (2007). “Understanding students’ information behaviour in relation to electronic information services: lesson from longitudinal monitoring and evaluation part 2." Journal of the American Society for Information Science and Technology, 58 (8), 1188-1197.

Urrehman, S. (2000). "Internet use and capabilities of library and information professionals at Kuwait University libraries: result of the survey.” Program, 34 (2), 177186.

Van Scoyoc, A. (2006). "The electronic academic library: undergraduate research behaviour in library without books.” Libraries and the Academy, 3 (2), 259-268.

Whitmire, E. (2002). “Disciplinary differences and undergraduates' information seeking behaviour." Journal of the American Society for Information Science and Technology, 53 (8), 631-638. 